\title{
Post-translational modifications and their applications in eye research (Review)
}

\author{
BING-JIE CHEN ${ }^{1-3}$, THOMAS CHUEN LAM ${ }^{3}$, LONG-QIAN LIU ${ }^{1,2}$ and CHI-HO TO ${ }^{3}$ \\ ${ }^{1}$ Department of Optometry and Visual Science, West China Hospital, Sichuan University, Chengdu, Sichuan 610041; \\ ${ }^{2}$ Institute for Disaster Management and Reconstruction, Sichuan University, Chengdu, Sichuan 610207; \\ ${ }^{3}$ Laboratory of Experimental Optometry, Centre for Myopia Research, School of Optometry, \\ The Hong Kong Polytechnic University, Hung Hom, Kowloon, Hong Kong, SAR, P.R. China
}

Received January 9, 2016; Accepted February 22, 2017

DOI: $10.3892 / \mathrm{mmr} .2017 .6529$

\begin{abstract}
Gene expression is the process by which genetic information is used for the synthesis of a functional gene product, and ultimately regulates cell function. The increase of biological complexity from genome to proteome is vast, and the post-translational modification (PTM) of proteins contribute to this complexity. The study of protein expression and PTMs has attracted attention in the post-genomic era. Due to the limited capability of conventional biochemical techniques in the past, large-scale PTM studies were technically challenging. The introduction of effective protein separation methods, specific PTM purification strategies and advanced mass spectrometers has enabled the global profiling of PTMs and the identification of a targeted PTM within the proteome. The present review provides an overview of current proteomic technologies being applied in eye research, with a particular focus on studies of PTMs in ocular tissues and ocular diseases.
\end{abstract}

\section{Contents}

1. Introduction

2. Proteomics analysis technology

Correspondence to: Professor Chi-Ho To, Laboratory of Experimental Optometry, Centre for Myopia Research, School of Optometry, The Hong Kong Polytechnic University, 11 Yuk Choi Road, Hung Hom, Hong Kong, SAR, P.R. China

E-mail: chi-ho.to@polyu.edu.hk; thomas.c.lam@polyu.edu.hk

Professor Long-Qian Liu, Department of Optometry and Visual Science, West China Hospital, Sichuan University, 37 Guoxue Xiang, Chengdu, Sichuan 610041, P.R. China

E-mail: b.q15651@hotmail.com

Key words: mass spectrometry, proteomics, post-translational modifications, ocular diseases
3. Introduction of PTMs

4. PTMs in eye research

5. Conclusion

\section{Introduction}

Over the last two decades, genomics has been regarded as the most popular and productive research field in biological science. However, the intermediate mRNA transcript may rapidly degrade (1) or undergo alternative splicing (2), which leads to a number of variable outcomes that renders the study of biological systems more challenging. Unlike ribosomal proteins or enzymes, which are relatively stable, the majority of proteins involved in the cell cycle demonstrate a rapid turnover rate and may function alongside a degradation process (3). As functional products of the biological system, proteins are direct and crucial participants in all downstream biochemical pathways.

Post-translational modification (PTM) is a key step in protein biosynthesis, whereby the addition, folding or removal of functional groups leads to drastic alterations in protein function (4). For instance, an Alzheimer's disease associated protein, Tau, is phosphorylated at 40 different sites, which produces site-specific phosphorylation that are responsible for different stages of the disease $(5,6)$. Large-scale studies of proteins and PTMs are often included in proteomic research at present. Robust peptide separation methods that employ strong cation exchange, high performance liquid chromatography (HPLC), novel mass spectrometry (MS) designs with high resolution and sensitivity, such as Orbitrap and TripleTOF, as well as PTM-specific bioinformatics tools and databases, have rendered the profiling of unique or multiple PTMs in biological proteomes possible. Proteomic analysis of PTMs has facilitated the identification of novel biomarkers for a number of diseases, including prostate cancer (7), pancreatic cancer (8) and rheumatoid arthritis (9). However, few proteomic-based studies have been performed to explore PTMs associated with eye diseases. It is thought that gaining an increased understanding of the characteristics of PTMs through the use of emerging MS techniques, is important for the development of effective diagnostic and therapeutic strategies for various disorders, including eye 
diseases (10). The present review will discuss the technological challenges in protein research, provide an overview of the types and mechanisms of PTMs, as well as their application in the research of eyes and associated diseases.

\section{Proteomics analysis technology}

Protein separation methods. Large-scale proteomic analysis typically involves gel-based and liquid chromatography-based separation strategies prior to MS analysis. It is possible to categorize these into electrophoretic and chromatographic approaches. For electrophoretic separation strategies, two-dimensional gel electrophoresis (2DE) has been widely used for separating soluble proteins based on their isoelectric points and molecular weights (11). However, membrane proteins, which serve vital functions in signal transduction pathways, are frequently difficult to separate using $2 \mathrm{DE}$ due to their high hydrophobicity (11). In addition, these approaches are technically insufficient due to a low dynamic range and throughput, which are important for analyzing complex biological samples. Therefore, the use of chromatography, including ion-exchange chromatography (12), hydrophobic interaction chromatography (13), size-exclusion chromatography (14), affinity chromatography (15), and the most popular, reverse-phase high-performance liquid chromatography $(16,17)$, have become the more common separation strategies used in high-throughput liquid chromatography-based proteomic research.

Protein identification strategies. MS has advanced qualitative and quantitative analysis of unknown organic and inorganic compounds in numerous fields, including environmental contaminant monitoring (18), forensic toxicology, doping analysis (19) and analysis of clinical samples (20), and is currently an indispensable tool in proteomics research. A typical mass spectrometer consists of an ionization source, a mass analyzer and a detector. Analytes are ionized to a gas phase and are subsequently processed by the mass analyzer and detector. The resultant mass spectra, expressed as mass/charge ratios, are compared with protein databases for identification (21).

Currently, there are two major ionization strategies employed for MS. The first is a matrix-assisted laser desorption/ionization (MALDI) approach, by which analyte desorption is induced by a laser beam and then absorbed by the matrix material (22). The molecules are then ionized to gases (23). The remaining approach is electrospray ionization (ESI), which was invented by Dole et al in 1968 (24). This technique was developed further by John Fenn, who was awarded a Nobel Prize in 2002 for this invention (25). Acidic liquid analytes acquire a positive electro-charge as they are sprayed into small droplets. They subsequently produce ions and enter the mass spectrometer. ESI allows a continuous flow of analytes with a variable flow rate, and generates multi-charged positive ions depending on the acidity of the solvent. This technique permits the identification of large molecular weight proteins by MS (26).

Collision-induced dissociation (CID) is the most widely used fragmentation method. It allows ions to collide with neutral gas molecules, which leads to internal energy conversion and fragmentation of the precursor ion (27). CID is effective in detecting small, low-charged peptides and single-charged ions (28); however, is not as effective at detecting long peptides. Due to the presence of PTMs, the digestion of long peptides by CID fragmentation becomes less effective. Therefore, liable PTMs, such as phosphorylation and S-nitrosylation, may be lost during CID collision (29). Furthermore, the presence of several basic amino acid residues in PTM proteins has been demonstrated to inhibit random protonation along peptide backbones by CID (28). These factors hinder the generation of efficient fragment ions by CID. To date, electron-transfer dissociation (ETD) is considered to be more favorable for PTM studies (30). This method transfers electrons to multi-protonated proteins or peptides, which leads to $\mathrm{N}-\mathrm{C} \alpha$ backbone bond cleavage. ETD is useful for the identification of liable PTMs. It provides the protein sequence information and modification sites, and it is frequently used for PTM analysis (31). Previous studies have reported that ETD is particularly suitable for detecting peptides with $>2$ charges $(32,33)$. However, it has been suggested that ETD yields a reduced number of identified proteins due to its lower scanning rate when compared with CID $(29,31)$. Several studies have compared the efficiency of CID and ETD in identifying PTMs (34-36). In general, CID and ETD are able to detect stable PTMs successfully, including acetylation and methylation, while ETD is the optimal strategy for identifying liable PTMs, including phosphorylation, ubiquitination and glycosylation. Multiple studies have suggested combining CID and ETD in order to gain higher competency and accuracy in PTM studies (34-40).

Protein quantification strategies. Advantages of applying large-scale proteomics strategies for biological research include profiling of the proteome for protein identification and quantification of protein expression. It is possible to achieve such quantification using chemical labeling strategies, in which the ion intensity between labeled and unlabeled peptides or differentially labeled peptides is compared. Isobaric tagging for relative and absolute quantification uses isobaric amine-specific tandem mass tags to label the $\mathrm{N}$-terminus and lysine residues of digested peptides. It is then possible to compare or analyze up to eight different sets of samples in a single experiment (41). Additional popular labeling strategies include isotope protein coded labeling (42), which uses isotope-coded tags instead of isobaric tags to label the $\mathrm{N}$-terminus and lysine residues. Dimethyl multiplexed labeling is an economical option, whereby the N-terminus of peptides and $\alpha$-amino groups of lysine residues are labeled with water-soluble formaldehyde via reductive methylation (28). Stable isotope labeling by amino acids in cell culture (SILAC) is an in vivo strategy, which involves feeding cell cultures with amino acids containing stable isotopes. During SILAC, lysates of labeled and normal cell cultures are mixed, digested and analyzed by MS, and the relative peak intensities in the MS spectrum are subsequently compared and analyzed (43). Despite the effectiveness of using labeling strategies in the quantification of the proteome, these are time-consuming, expensive and complicated in terms of sample preparation procedures and data analysis. Novel and accurate label-free quantification methods are gradually emerging.

Label-free quantification is a fast and low-cost strategy for measuring large-scale differential proteomic expression. 
Table I. List of typical and important PTMs and their biological significance.

\begin{tabular}{|c|c|c|}
\hline PTMs & Modification subtypes & Biological functions \\
\hline Phosphorylation & $\begin{array}{l}\text { pSer, pThr, pTyr (most common), } \\
\text { pHis, pCys and pAsp (least common) }\end{array}$ & $\begin{array}{l}\text { Reversible; regulating signaling pathways by } \\
\text { activating and inhibiting enzymes }\end{array}$ \\
\hline Glycosylation & $\begin{array}{l}\text { N-linked, O-linked, C-mannosylation } \\
\text { and GPI anchor. }\end{array}$ & $\begin{array}{l}\text { Molecular interaction; signal } \\
\text { transduction; cell recognition }\end{array}$ \\
\hline Acetylation & $\begin{array}{l}\text { N-terminal (most common), } \\
\text { C-terminal and histone (less common) }\end{array}$ & $\begin{array}{l}\text { Reversible; protein localization, stability and } \\
\text { synthesis; cell-to-cell interaction; apoptosis }\end{array}$ \\
\hline Ubiquitination & - & Protein degradation \\
\hline Sumoylation & - & $\begin{array}{l}\text { Reversible; protein-protein interaction, } \\
\text { protein stability and localization }\end{array}$ \\
\hline Methylation & $\mathrm{N}$-/O-terminal & Gene transcription and signal transduction \\
\hline Lipidation & $\begin{array}{l}\text { GPI anchors, N-myristoylation, } \\
\text { S-palmitoylation and S-prenylation }\end{array}$ & Protein activities and targeting \\
\hline
\end{tabular}

PTM, post-translational modification; GPI anchor, glycosylphosphatidylinositol anchor.

These approaches are divided into two major strategies; the first requires cross-checking of the numbers of MS/MS spectra acquired for peptides of proteins between different standard samples (44), and the second strategy is based on the measurement and comparison of chromatographic peak areas of peptide precursor ions between different samples (45). There are currently multiple open source and commercial software packages available for the processing of label-free quantification data, including MZmine, MsInspect, MapQuant, SIEVE, Elucidator and OpenSWATH for SWATH analysis (46-49). These software programs facilitate peak detection and matching, data alignment, normalization and statistical analysis. However, limitations, such as the variation between different samples, remain a major concern.

\section{Introduction of PTMs}

To date, $>400$ types of PTMs have been reported, and >90,000 individual PTMs have been identified (50). Glycosylation, ubiquitination, phosphorylation, methylation and acetylation are commonly reported (4), while additional PTMs, such as adenosine monophosphate adenylation, are less frequently reported (51). As PTMs influence almost every aspect of cell biology, they are an important molecular factor for understanding biological and pathological mechanisms, and are summarized in Table I.

Phosphorylation. Phosphorylation is a chemical reaction that involves the transfer of a phosphate group from the $\gamma$-locus of adenosine 5'-triphosphate (ATP) or guanosine 5'-triphosphate to the side chain of an amino acid residue of a substrate protein molecule. This reaction is mediated by protein kinase catalysis, whereas its counterpart enzyme, phosphatase, catalyzes the de-phosphorylation reaction (52). Phosphorylation is the most widely studied PTM, due to its involvement in a wide range of cellular functions. For instance, it activates or inhibits various enzymes or receptors, thus regulating different signaling pathways that govern cell metabolism, growth and differentiation, the immune response, oncogenesis and apoptosis (53-55). Phosphorylation of eukaryotic proteins has been demonstrated to occur most commonly on serine, threonine and tyrosine residues, which mediates the activity of numerous signaling networks involved in cell differentiation and proliferation (56). A higher frequency of phosphorylation on serine and threonine residues occurs when compared with tyrosine residues at a ratio of $\sim 1,800: 200: 1$ (pSer: pThr: pTyr) (57). By contrast, phosphorylation of histidine, cysteine and aspartate residues has been reported in bacteria, fungi and plants, as part of bi- and multi-component phospho-signaling transduction pathways $(58,59)$. Furthermore, phosphorylation of histidine has been demonstrated to be involved in regulating metabolic signaling pathways in eukaryotic cells $(60,61)$. In the last decade, various human genome projects have confirmed that genes coding for kinases and phosphatases comprise $>2 \%$ of the human genome (62). In total, $\sim 30 \%$ of the whole human proteome has been postulated to undergo phosphorylation during its life cycle (63).

Glycosylation. Glycation (non-enzymatic glycosylation) is the covalent bonding of a carbohydrate molecule to another molecule, which may occur under in vivo or in vitro conditions (64). In biological systems, the process of attaching glycans to lipids, proteins or additional organic molecules by catalysis is termed glycosylation (65). It is possible to divide glycosylation into four main subcategories, including $\mathrm{N}$-linked and O-linked glycosylation, C-mannosylation and the glycosylphosphatidylinositol (GPI) anchor. N-linked glycosylation involves the attachment of an oligosaccharide to aspartic acid residues of secreted or membrane-bound proteins, and occurs primarily in the endoplasmic reticulum of eukaryotic cells (66). A similar binding strategy occurs between various sugars and serine and threonine residues primarily in the Golgi, nucleus and cytoplasm (67), termed O-linked glycosylation. C-mannosylation refers to the addition of a mannose oligosaccharide to the first tryptophan residue in the amino acid sequence via a carbon-carbon bond (68). Formation of the GPI anchor involves the covalent linkage of the $\mathrm{C}$-terminus of a protein with the glycolipid portion of the membrane phospholipid located 
on the extracellular side of the plasma membrane (69). This occurs in $>50 \%$ of proteins (70) and affects multiple molecular activities, including the regulation of cellular interactions, signal transduction and molecular interactions. In addition, GPI anchors affect processes including the pathogenesis of several diseases, such as paroxysmal nocturnal hemoglobinuria (71), immunological protection, intercellular adhesion, cellular proliferation, inflammation, oncogenesis and viral replication $(72,73)$.

Acetylation. Acetylation is the process of adding an acetyl group to a molecule. Its counterpart reaction, de-acetylation, is the removal of the acetyl group from a chemical compound. Acetylation of various proteins, including histone (74), p53 (75) and tubulin (76) have been reported. According to previous studies, three main categories of acetylation have been identified thus far; N-terminal acetylation, histone acetylation and acetylation of C-terminal residues (75,77). N-terminal acetylation is one of the most common PTMs and is catalyzed by $\mathrm{N}$ - $\alpha$-acetyltransferases, which have been demonstrated to be expressed in $>50 \%$ of cytosolic yeast proteins (78) and $\sim 80-90 \%$ of mammalian proteins (78). $\mathrm{N}$-acetylation is known to affect protein stability and prevent or generate specific degradation signals (79-81). It is involved in regulating and determining protein localization $(82,83)$, as well as regulating the cellular life cycle and apoptosis $(84,85)$. Previous studies have demonstrated its importance in protein synthesis (86) and protein-protein interactions $(85,86)$. The $\alpha$-amino group of histone lysine residues was revealed to be consistently acetylated or de-acetylated by enzymes $(87,88)$, which was subsequently demonstrated to be pivotal in regulating gene expression $(79,89)$. Further studies have confirmed a close association between histone acetylation and the regulation of gene transcription in inflammation and cancers of the immune system (90-92). In addition, acetylation of C-terminal serine and threonine residues has been observed (93). Acetylation has been suggested to compete with phosphorylation of these C-terminal amino acid residues (94), and thus may be involved in regulating phosphorylation-associated signaling pathways. However, a more complete understanding of the involvement of C-terminal acetylation on PTMs remains to be elucidated.

Ubiquitination and sumoylation. Ubiquitin is a highly conserved protein (76 amino acids in length) that is abundant in eukaryotic cells. The process by which the last amino acid residue of ubiquitin is attached to a lysine residue of a protein by enzymatic catalysis is known as ubiquitination (95). The ubiquitin-bound protein then undergoes sequential reactions catalyzed by three different enzymes, namely ubiquitin-activating enzyme (E1), ubiquitin-conjugating enzyme (E2) and ubiquitin ligase (E3). Ubiquitination is commonly involved in the intercellular degradation of proteins, such as short-life and abnormal-life proteins (95). Abnormalities in the ubiquitin system have been associated with a number of pathogeneses, including neurodegenerative disorders $(96,97)$, malignancies $(98,99)$ and immunological disorders $(100,101)$.

In a previous study, a reversible PTM modifier known as the small ubiquitin-like protein modifier (SUMO), was identified (76). The SUMO protein is covalently bound to a variety of proteins at their lysine residues. This process is known as sumoylation, which is mediated by the SUMO-specific E1-activating enzyme heterodimer termed activator of Sentrin/SUMO-ubiquitin-like modifier activating enzyme 2, the E2 conjugating enzyme UBC9 and SUMO E3 ligase (102-105). SUMO proteins are ubiquitously expressed in numerous biological systems, and previous studies have demonstrated that a high frequency of sumoylation occurs in cell nuclei $(106,107)$. Additional studies have revealed that sumoylation occurs in additional cellular structures, including the plasma membrane (108), endoplasmic reticulum (109) and mitochondria (110). Four SUMO protein isoforms, SUMO1, SUMO2, SUMO3 and SUMO4, have been identified in humans thus far (111). Although SUMO is functionally similar to ubiquitin, it has not been demonstrated to promote protein degradation, and is instead involved in a number of additional molecular reactions. For instance, it affects protein-protein interactions $(108,112,113)$, promotes intracellular protein trafficking and localization (114-116) and prevents protein degradation (117).

Additional types of PTMs. In addition to the aforementioned PTMs, previous studies have demonstrated that a number of relatively simple, yet significant additional PTMs have been identified. For instance, oxidation of specific amino acids as a result of exposure to oxidative stress, activates in vivo protease activities, which leads to apoptosis induction $(118,119)$. The transfer of a carbo-methyl group by methyltransferases to the $\mathrm{N}$ - or O-terminal of histidine, proline, arginine, lysine or carboxyl groups (known as methylation), is associated with a number of vital biological functions, such as gene transcription and signal transduction $(120,121)$. By contrast, the lipidation PTM describes the covalent binding of various lipids to peptide chains. This PTM is subdivided into GPI anchors, N-myristoylation, S-palmitoylation and S-prenylation (122). In addition, lipidation has been demonstrated to affect the function of proteins and membrane proteins by further increasing their hydrophobicity (123).

Sample purification and enrichment methods prior to MS analysis. Despite advancements in improving the sensitivity of HPLC/MS systems, together with progress in the generation of powerful algorithms for database searching, the efficiency of PTM identification by proteomic approaches remains unsatisfactory. The identification of low-abundant PTM proteins remains a major challenge, as their MS signals are easily disguised by more abundant non-PTM proteins in a complex mixture. Therefore, extensive purification and enrichment of PTM proteins is necessary prior to the performance of mass analysis. Antibody-based affinity purification has been widely used to purify target proteins with specific PTMs. This approach has been adopted successfully for the analysis of tyrosine phosphorylation (124), arginine methylation (125) and lysine acetylation (126), in order to enhance the sensitivity and accuracy of PTM identification. However, the running costs of this enrichment procedure are relatively high. Alternatively, chemical tagging is a common approach for labeling PTMs for in vivo and in vitro studies. Chemical tags are sequentially conjugated to affinity linkers, such as biotin (127) or lectin (128). Biotin-containing tags have been successfully used to isolate proteins with PTMs including S-nitrosylation (129), O-linked 
Table II. Overview of purification strategies for PTMs.

Purification/

enrichment

strategies

Antibody-based

affinity purification

Antibody

Ligands

PTMs

Advantages

Drawbacks/

limitations tagging

Chemical derivative

In vivo metabolic

and in vitro

chemical

tagging
Tyrosine phosphorylation, arginine methylation, lysine acetylation

Farnesylation (in vitro), O-GlcNAc modification (in vivo and in vitro), palmitoylation (in vitro), myristoylation (in vitro), glycosylation (in vitro), oxidation (in vitro)
High specificity

Small PTM alterations are difficult to identify; generation of antibodies against poorly antigenic PTMs is difficult

Wider enrichment range of PTMs
Sample loss; unwanted side products; non-specific binding

PTM, post-translational modification; O-GlcNAc, O-linked $\beta$-D-N-acetylglucosamine.

Table III. Overview of chromatography phospho-enrichment strategies.

\begin{tabular}{|c|c|c|c|}
\hline Strategy & Ligands & Advantages & Drawbacks/limitations \\
\hline IMAC & $\begin{array}{l}\text { Metal ions }\left(\mathrm{Al}^{3+}, \mathrm{Fe}^{3+}\right. \\
\left.\mathrm{Ga}^{3+}\right) \text { immobilized on } \\
\text { a matrix via acidic } \\
\text { compounds (IDA, } \\
\text { NTA, TED) }\end{array}$ & $\begin{array}{l}\text { High purification capacity } \\
\text { of phosphopeptides from } \\
\text { complex samples. }\end{array}$ & $\begin{array}{l}\text { Poor affinity of mono-phosphopeptides; } \\
\text { non-specific binding of } \\
\text { non-phosphorylated peptides with } \\
\text { multi-acidic amino acid residues } \\
\text { or nucleic acid; susceptible to be } \\
\text { influenced by experimental conditions. }\end{array}$ \\
\hline MOAC & $\begin{array}{l}\text { Metal oxide }\left(\mathrm{TiO}_{2}\right. \\
\left.\mathrm{ZrO}_{2}, \mathrm{Al}(\mathrm{OH})_{3}\right)\end{array}$ & $\begin{array}{l}\text { High selectivity and } \\
\text { sensitivity for complex } \\
\text { sample; high tolerance of } \\
\text { solvent pH. }\end{array}$ & $\begin{array}{l}\text { Poor affinity of multi-phosphopeptides; } \\
\text { non-specific binding of acidic } \\
\text { non-phosphorylated peptides. }\end{array}$ \\
\hline SIMAC & $\mathrm{IMAC}+\mathrm{MOAC}$ & $\begin{array}{l}\text { Increase the number of } \\
\text { discovered phosphoproteins; } \\
\text { increase the phosphopeptide } \\
\text { spectrum. }\end{array}$ & Complex operation steps. \\
\hline
\end{tabular}

IMAC, immobilized metal affinity chromatography; MOAC, metal oxide affinity chromatography; SIMAC, sequential elution from IMAC; IDA, iminodiacetic acid; NTA, nitrilotriacetic acid; TED, ethylenediamine.

$\beta$-D-N-acetylglucosamine (130) and palmitoylation (131). In addition, multiple glycoproteomics studies have adopted the lectin-based affinity enrichment method (132-134). However, there are a number of limitations associated with these methods, which are summarized in Table II.

Ionic interaction-based enrichment of phosphoproteins or phosphopeptides is currently the most successful and widely used strategy to achieve phosphoproteomic enrichment. Immobilized metal affinity chromatography (IMAC) utilizes metal cations to target the negatively-charged phosphate group and the positively-charged metal ions, which are bound to resins via acidic linkers (Table III). These are subsequently eluted using a buffer with increasing $\mathrm{pH}(135,136)$. Previous reports have demonstrated that IMAC enriches the total phosphoprotein content of a complex sample by up to $90 \%$ (137). An alternative method of enrichment is metal oxide affinity chromatography (MOAC) (138). In this strategy, the phosphopeptides are trapped by metal oxide ligands in an acidic solvent, and are consequently desorbed and eluted under alkaline conditions. MOAC exhibits higher selectivity and sensitivity for phosphopeptide enrichment compared with traditional phosphoprotein enrichment methods, such as ${ }^{32} \mathrm{P}$ labeling (139). In addition, a stronger affinity for phosphopeptides has been observed in MOAC when compared with IMAC (138). The advantages and limitations of these phospho-enrichment strategies are summarized in Table III. In general, IMAC appears to be effective for the enrichment of multi-phosphopeptides, while MOAC favors mono-phosphopeptide enrichment. In 2008, 
Thingholm et al (140) introduced an enrichment strategy known as sequential elution from IMAC (SIMAC), which combines the two phosphopeptide enrichment strategies with the aim of overcoming the limitations of either technique in isolation. In this combined protocol, IMAC was initially used to enrich multi-phosphopeptides, whilst mono-phosphorylated peptides were eluted by an acidic solvent. The solution was then further enriched by $\mathrm{TiO}_{2}$. Using this approach, SIMAC was able to identify a $>2$-fold higher number of phosphorylated sites when compared with the total number identified by $\mathrm{TiO}_{2}$ enrichment alone (140). This combined strategy has successfully increased the phosphopeptide spectrum, and a more comprehensive understanding of protein phosphorylation patterns may be gained (140).

\section{PTMs in eye research}

Proteomic studies of multiple PTMs in ocular tissues have improved our understanding of the physiology or pathology of various ocular conditions. The discovery of co-existing modifications of specific proteins, suggests that mechanisms of disease pathogenesis may involve interplay among these PTMs. The discovery of novel PTM sites on proteins and the study of differential PTM expression patterns have revealed a number of candidates that may be involved in different pathogenic signaling pathways. Using cutting-edge proteomic technology, novel biomarkers for the early diagnosis of ocular diseases are emerging, which may promote the development of novel therapeutic strategies to treat ocular diseases.

Tears. The surface of the eyes is overlaid by the tear film, which consists of lipid, aqueous and mucous layers (141). Alterations in any component of the tears may reflect underlying functional disorders of ocular structures, such as the secretary glands or the cornea, and may be an indicator of abnormal systemic conditions. The accessibility of the tear film is a desirable factor when searching for biomarkers in various ocular conditions, including dry eye syndrome, autoimmune thyroid eye disease (142) and diseases of the cornea (143). The proteome of human tears has been well-profiled and thousands of proteins have been identified $(144,145)$. Proteins have been demonstrated to be differentially expressed in the tears of patients with dry eye syndrome (146), keratoconus (147), diabetic retinopathy (148) and in those treated with chronic glaucoma medication (149). Studies investigating the PTM alterations in tears have been performed using proteomic technology. For instance, O-acetylation of sialic acid derivatives on membrane-associated mucins was identified in human tears by the use of LC-MS/MS, and the results suggested that this PTM may be involved in protecting the cellular surface from infection (150). An additional study adopted the hydrazide-resin capture method to enrich N-Linked glycoproteins in the tears of patients undergoing climatic droplet keratopathy, in which 19 unique $\mathrm{N}$-glycosylated proteins were reported for the first time (151). In a study of human tears, three sequential dyes were used to stain phospho-, glycol- and total proteins following 2D-PAGE separation, and a number of novel proteins including dermcidin, glycosylated lipocalin 1, cystatin S, phosphorylated nucleobindin 2 were identified and their potential ocular functions were discussed (152). In addition, the protein profile of tears from patients with ocular rosacea was revealed using glycan-released, glycan-enriched and solid-phase extraction methods with MS analysis. In total, 50 N-glycans and $70 \mathrm{O}$-glycans were profiled, and fucosylated $\mathrm{N}$-glycans were revealed to be significantly underexpressed while sulfated O-glycans was over-expressed. These factors made them potential markers to consider for this particular ocular status (153). Detailed profiling of proline-rich protein 4 , a potential biomarker of lacrimal gland acinar cell function (154), in normal human tears was conducted by applying one- and two-dimensional MS analysis. Four co-existing PTMs including methylation, acetylation, oxidation, and the addition of pyroglutamate were identified in human tear samples; however, their functions in physiological and pathological processes have yet to be elucidated (155).

Cornea. The cornea is the outermost and key refractive structure of the eye. For this unique structure, $>3,000$ proteins have been identified by comprehensive proteomic profiling thus far (156). In 2011, phosphorylated sites on mammary serine protease inhibitor (maspin) from human extracellular corneal cells were mapped by nano-HPLC-ESI-MS following immunoprecipitation (157). A total of 8 serine and threonine phosphorylation sites were revealed, while no phosphorylated tyrosine residues were observed (157). These results may enable clarification of the role of selective phosphorylation of maspin in the corneal epithelium during wound healing and anti-angiogenesis. In response to mechanical injury, epidermal growth factor receptor in the corneal epithelium was demonstrated to undergo multiple phosphorylations as revealed by a study using a proteomic workflow (158). In addition, N-glycans and glycosaminoglycans were profiled in a comparative manner in Statens Seruminstitut rabbit corneal (SIRC) cells and rabbit corneal epithelial cells using HPLC-MS. The high mannose-type and a hybrid type of N-glycan were demonstrated to be the most abundant types in SIRC cells, and this observation was considered to have an important pharmaceutical value (159).

Crystalline lens. The crystalline lens is a transparent and biconvex structure that functions to refract light rays by altering its curvature. The lens proteome has been thoroughly characterized, with particular interest focused on its association with cataracts. Cataracts, which is elicited by normal aging or various pathologies, is the leading cause of blindness worldwide (160). The association between $\alpha-, \beta$ - and $\gamma$-members of the crystallin family has been the focus of cataract research for decades. The assemblage of PTMs, including phosphorylation and deamidation in crystallins, was demonstrated to contribute significantly to the formation of cataracts in different animal species (161-171). In addition, the function of phosphorylation in the crystallin family has gained attention, and profiling studies concerning phosphorylated sites in the lens proteome using phospho-enrichment strategies are summarized in Table IV. Using IMAC followed by LC-MS/MS analysis, novel phosphorylation sites have been identified on $\alpha \mathrm{A}-$ and $\alpha \mathrm{B}$-crystallins, as well as on additional proteins, including $\beta$-enolase, heat shock protein 27 and glucose-6-phosphate 
Table IV. Summary of identified PTMs on crystallins using the mass spectrometry approach.

\begin{tabular}{ll}
\hline PTM subtypes & Species \\
\hline$\alpha$-crystallin & Mouse \\
Phosphorylation of soluble $\alpha$ A- and $\alpha$ B-crystallins & Mouse \\
Phosphorylation of $\alpha$ A-crystallin on Ser122 and Ser148 & Rat (OXY cataract model) \\
Oxidation of Met, deamidation of Asp and Glu, phosphorylation of & \\
Ser and Thr residues & Mouse \\
Phosphorylation of Tyr4, Ser20, Ser45, Ser59, Ser148, Ser155, & \\
Ser172/173, N-acetylation and C-truncation of $\alpha$ A-crystallin & Human \\
Isomerization of several Asp residues & \\
$\beta$-crystallin & Bovine \\
Phosphorylation and acetylation of $\beta$ H-crystallin & \\
$\gamma$-crystallin & Human \\
Oxidation of W136 and additional Tyr residues & Human \\
Acetylation of Lys2 and Gly1 of $\gamma D$-crystallin & \\
Multiple subtypes of crystallins & Human \\
Deamidation, oxidation, ethylation, phosphorylation, methylation, \\
$\begin{array}{l}\text { acetylation, and carbamylation } \\
19 \text { phosphorylation proteins }(28 \text { phosphorylated sites) }\end{array}$ \\
\hline
\end{tabular}

PTM, post-translational modification.

isomerase (172). Furthermore, differential expression patterns of phosphoproteins have been observed in human cataract lens extracts, in which 28 novel sites were identified as being differentially phosphorylated (173).

In a previous study investigating PTMs in the lens membrane, the most abundant lens membrane protein, aquaporin 0 (AQP0), was demonstrated to be phosphorylated on serine 235 and serine 229 (174). It was also revealed to be truncated at specific residues and racemized/isomerized on two aspartic acid residues, i.e. Asn 259 and Asn 246, in normal human lens cells. In addition, the spatial distribution of PTMs in the bovine lens was investigated, and serine 235 of AQP0 was demonstrated to be significantly phosphorylated in the nuclear and equatorial cortex regions, while C-terminal truncation of AQP0 was detected in the nuclear region. Furthermore, truncations of connexin 50 and connexin 46 were observed primarily in the nuclear region, and the corresponding expression levels of these proteins was significantly lower in the anterior outer cortex region (175). Novel PTMs of AQP0, including fatty acid acylation of the bovine and human lens protein, and an oleic acid modification to a lysine residue, have been detected by direct tissue proteomic profiling (176). These results suggest that various PTMs exist on AQP0, and that these PTMs may be associated with its biochemical functions, and particularly during the aging process of the crystalline lens.

Vitreous humor. Profiling of the human vitreous humor proteome has been completed, with at least 460 non-redundant proteins being catalogued; however, the PTMs of these proteins remain to be elucidated (177). The proteome of the vitreous humor of rats with experimental autoimmune uveitis (EAU) has been previously analyzed using 2D-PAGE,
MALDI-time of flight (TOF)/MS and micro-LC/LC-MS/MS approaches. Truncations of $\alpha \mathrm{A}$ - and $\alpha \mathrm{B}$-crystallin and phosphorylation of $\alpha \mathrm{B}$-crystallin were identified in the EAU group, indicating that these PTMs may be crucial in regulating the inflammatory reaction during uveitic conditions (178). In a rat model of ischemia-reperfusion (I/R) injury, the vitreous proteome was studied using 2D-PAGE and MALDI-TOF-MS technology (179). The results revealed an increase in the phosphorylation of three serine residues on $\alpha \mathrm{B}$-crystallin, and a decrease in extracellular signal related kinase $1 / 2$ phsophorylation at $48 \mathrm{~h}$ following I/R injury. It has been suggested that phosphorylation of $\alpha \mathrm{B}$-crystallin may be involved in suppression of the inflammatory process in I/R.

Retina. A number of previous studies have investigated retinal proteomes, and the proteomic alterations that occur in response to various retinopathies (180-183). In terms of PTMs, a previous study profiling porcine rhodopsin documented an extensive phosphorylation pattern on the $\mathrm{C}$-terminus and unusual glycosylation pattern, which is a significant discrepancy when compared with that observed in bovine and rat rhodopsin proteins (184). Among the 13 differentially expressed mitochondrial proteins in normal mice and those with early experimental autoimmune uveitis, oxidation and carbamidomethylation were revealed to be the most common PTMs (185). By contrast, pre-isolation by column chromatography coupled with ESI-triple-quadrupole MS, enabled the characterization of bovine cone transducin (T $\gamma), \mathrm{T} \beta 3 \alpha 8$, which is similar to $\mathrm{T} \beta 1 \gamma 1$ following isoprenylation. This suggested a weak involvement of the interaction between $\mathrm{T} \beta 3 \alpha 8$ and phosducin during cone specialization (186). A similar top-down proteomic study of the isoprenylation of transducin examined the rod outer segment membrane of mice. In this study, similar modification 
sites were observed on murine $\mathrm{T} \gamma$ when compared with those in bovine $\mathrm{T} \gamma$ (187). Using the proteomic PTM approach, a high heterogeneic pattern of glycosylation on the 5-hydroxytryptamine receptor $4\left(5-\mathrm{HT}_{4} \mathrm{R}\right)$ in $5-\mathrm{HT}_{4} \mathrm{R}$-containing rod cells was discovered in transgenic mice (188). The use of SDS-PAGE, $\mathrm{TiO}_{2}$ phosphopeptide enrichment and LC-MS/MS has revealed seven N-glycosylation sites and five phosphorylation sites on the ATP-binding cassette, subfamily A, member 4 protein in bovine rod outer segments, which has been suggested to be part of the disease mechanism in Stargardt disease (189). In addition, proteomic research has contributed to understanding the dynamic nature of histones in the I/R injured rat retina. With the application of linear ion trap-orbitrap hybrid MS/MS analysis, 34 histone PTMs were revealed to be differentially expressed in this ocular condition, of which three histone $\mathrm{H} 4$ marks were further confirmed by western blotting (190). This indicated that these histone PTMs may predispose towards DNA damage following I/R injury (190).

The increasing global prevalence of myopia in recent decades, especially in eastern Asian countries, such as China, Japan and Singapore, make it a non-negligible health issue $(191,192)$. The morbidity of myopia can reach up to $80-90 \%$ in younger age groups in these areas $(193,194)$. Previous studies have demonstrated that the retina is the major site that receives signals and determines the extent of eyeball elongation $(195,196)$. Thus far, proteomic research has revealed a number of candidate proteins that may be associated with myopic eye growth (197-199). However, none of these studies have specifically focused on PTMs. The first global screening of the retinal phosphoproteome in a myopic chick model was conducted using $\mathrm{TiO}_{2}$ enrichment and nano-LC-TripleTOF MS/MS analysis (200). In this pilot study, 560 phosphoproteins were profiled, in which 45 were upregulated and 30 were downregulated during myopic eye growth. In addition, using the phosphoenrichment approach, acetylated retinal proteins including carbonic anhydrase, ubiquitin carboxyl-terminal hydrolase and fatty acid-binding protein were revealed to be upregulated while nucleophosmin, 40S ribosomal protein S12 and histone $\mathrm{H} 1 \mathrm{x}$ were significantly downregulated in myopic eyes. These results may provide an insight into the analysis of retinal phosphoproteome alterations during myopic eye growth.

Retinal pigment epithelium (RPE). The single layer of pigmented cells located on the outside of the neurosensory retina, is known as the RPE, which functions primarily to nourish and support the photoreceptors. Alterations in the PTMs of proteins have been studied in RPE cells following exposure to light. The results indicated that phosphorylation of cystallins may be important in protecting RPE against light-induced oxidative damage (201). In addition, profiling of the secretome in bovine RPE demonstrated the presence of three tyrosine-sulfated proteins. This included tyrosine-sulfated complement factor $\mathrm{H}$, which may be involved in age-associated macular degeneration (202). Following $\mathrm{H}_{2} \mathrm{O}_{2}$ challenge, a novel $45 \mathrm{kDa}$ truncated modification on the retinoid isomerohydrolase (RPE65) protein was identified by LC-MS/MS in murine RPE, suggesting that the RPE65 cleavage process may be affected by oxidative stress (203). The results of a previous MS-based study put into question the conventional belief that the palmitoylation of cysteine residues on RPE65 is responsible for membrane affinity (204). However, neither palmitoylation nor additional PTMs were identified on RPE65 in this study.

\section{Conclusion}

Proteomic approaches have evolved tremendously in the past decade. Previous methods for protein separation and fractionation limited the study of PTMs; however, advances in enrichment methods have overcome these limitations and enabled the identification of different disease-specific PTM-associated biomarkers in ocular diseases $(151,172,173)$. This progress will improve our understanding of different ocular disease mechanisms, and will be useful for the development of novel diagnostic strategies to improve treatment efficiency. Although research into proteomic PTMs in ocular diseases is at a preliminary stage, the continuous improvement of proteomics technologies will facilitate a more detailed study of PTMs and their applications in ocular therapy in the near future.

\section{Acknowledgements}

The present review was supported by The Hong Kong Jockey Club and the Institute for Disaster Management and Reconstruction of Sichuan University (grant no. Fund5-6W0G), the Hong Kong Research Grants Council General Research Fund (Research Grants Council/General Research Fund grant nos. PolyU 5626/11M and PolyU 151033/15M), the Henry G Leong Endowed Professorship and the Hong Kong Polytechnic University (grant nos. GU839, GU986, Z0GK, GYBBU, GYK89 and GYZ29).

\section{References}

1. Gygi SP, Rochon Y, Franza BR and Aebersold R: Correlation between protein and mRNA abundance in yeast. Mol Cell Biol 19: 1720-1730, 1999.

2. Black DL: Mechanisms of alternative pre-messenger RNA splicing. Ann Rev Biochem 72: 291-336, 2003.

3. Belle A, Tanay A, Bitincka L, Shamir R and O'Shea EK: Quantification of protein half-lives in the budding yeast proteome. Proc Natl Acad Sci USA 103: 13004-13009, 2006.

4. Higgins SJ and Hames BD: Post-translational Processing: A Practical Approach. Oxford University Press, Oxford, 1999.

5. Amniai L, Barbier P, Sillen A, Wieruszeski JM, Peyrot V, Lippens G and Landrieu I: Alzheimer disease specific phosphoepitopes of Tau interfere with assembly of tubulin but not binding to microtubules. FASEB J 23: 1146-1152, 2009.

6. Augustinack JC, Schneider A, Mandelkow EM and Hyman BT: Specific tau phosphorylation sites correlate with severity of neuronal cytopathology in Alzheimer's disease. Acta Neuropathol 103: 26-35, 2002.

7. Kyselova Z, Mechref Y, Al Bataineh MM, Dobrolecki LE, Hickey RJ, Vinson J, Sweeney CJ and Novotny MV: Alterations in the serum glycome due to metastatic prostate cancer. J Proteome Res 6: 1822-1832, 2007.

8. Zhao J, Qiu W, Simeone DM and Lubman DM: N-linked glycosylation profiling of pancreatic cancer serum using capillary liquid phase separation coupled with mass spectrometric analysis. J Proteome Res 6: 1126-1138, 2007.

9. Rombouts Y, Willemze A, van Beers JJ, Shi J, Kerkman PF, van Toorn L, Janssen GM, Zaldumbide A, Hoeben RC, Pruijn GJ, et al: Extensive glycosylation of ACPA-IgG variable domains modulates binding to citrullinated antigens in rheumatoid arthritis. Ann Rheum Dis 75: 578-585, 2016. 
10. Ceciliani F, Eckersall D, Burchmore R and Lecchi C: Proteomics in veterinary medicine: Applications and trends in disease pathogenesis and diagnostics. Vet Pathol 51: 351-362, 2014.

11. Rabilloud T: Two-dimensional gel electrophoresis in proteomics: Old, old fashioned, but it still climbs up the mountains. Proteomics 2: 3-10, 2002.

12. Williams A and Frasca V: Ion-Exchange Chromatography. Curr Protoc Protein Sci Chapter 8: Unit8.2, 2001.

13. Queiroz J, Tomaz C and Cabral J: Hydrophobic interaction chromatography of proteins. J Biotechnol 87: 143-159, 2001

14. Lecchi P, Gupte AR, Perez RE, Stockert LV and Abramson FP: Size-exclusion chromatography in multidimensional separation schemes for proteome analysis. J Biochem Biophys Methods 56: 141-152, 2003.

15. Lee WC and Lee KH: Applications of affinity chromatography in proteomics. Anal Biochem 324: 1-10, 2004.

16. McCue JT: Theory and use of hydrophobic interaction chromatography in protein purification applications. Methods Enzymol 463: 405-414, 2009.

17. Issaq HJ, Chan KC, Blonder J, Ye X and Veenstra TD: Separation, detection and quantitation of peptides by liquid chromatography and capillary electrochromatography. J Chromatogr A 1216: $1825-1837,2009$

18. Petrovic M and Barceló D: Liquid chromatography-mass spectrometry in the analysis of emerging environmental contaminants. Anal Bioanal Chem 385: 422-424, 2006.

19. Rivier L: Criteria for the identification of compounds by liquid chromatography-mass spectrometry and liquid chromatography-multiple mass spectrometry in forensic toxicology and doping analysis. Analytica Chimica Acta 492: 69-82, 2003.

20. Chace DH: Mass spectrometry in the clinical laboratory. Chem Rev 101: 445-477, 2001

21. Deutsch EW, Lam H and Aebersold R: Data analysis and bioinformatics tools for tandem mass spectrometry in proteomics. Physiol Genomics 33: 18-25, 2008.

22. Zaluzec EJ, Gage DA and Watson JT: Matrix-assisted laser desorption ionization mass spectrometry: Applications in peptide and protein characterization. Protein Expr Purif 6: 109-123, 1995

23. Kaufmann R: Matrix-assisted laser desorption ionization (MALDI) mass spectrometry: A novel analytical tool in molecular biology and biotechnology. J Biotechnol 41: 155-175, 1995.

24. Dole M, Mack LL and Hines more RL: Molecular beams of macroions. J Chemical Physics 49: 2240, 1968.

25. Yamashita M and Fenn JB: Electrospray ion source. Another variation on the free-jet theme. J Phys Chem 88: 4451-4459, 1984

26. Kinter $M$ and Sherman NE (eds): Protein Sequencing and Identification Using Tandem Mass Spectrometry. Wiley-Interscience, 2000.

27. Kraj A and Silberring J: Proteomics: Introduction to Methods and Applications. John Wiley \& Sons, Hoboken, NJ, 2008.

28. Elviri L: ETD and ECD mass spectrometry fragmentation for the characterization of protein post translational modifications. In: Tandem Mass Spectrometry-Applications and Principles. Prasain JK (ed). InTech, pp161-178, 2012.

29. Quan L and Liu M: CID, ETD and HCD fragmentation to study protein post-translational modifications. Mod Chem Appl 1: $\mathrm{e} 102,2013$

30. Hayakawa S, Matsumoto S, Hashimoto M, Iwamoto K, Nagao H, Toyoda M, Shigeri Y, Tajiri M and Wada Y: High-energy electron transfer dissociation (HE-ETD) using alkali metal targets for sequence analysis of post-translational peptides. J Am Soc Mass Spectrom 21: 1482-1489, 2010.

31. Guthals A and Bandeira N: Peptide identification by tandem mass spectrometry with alternate fragmentation modes. Mol Cell Proteomics 11: 550-557, 2012.

32. Altelaar AM, Mohammed S, Brans MA, Adan RA and Heck AJ: Improved identification of endogenous peptides from murine nervous tissue by multiplexed peptide extraction methods and multiplexed mass spectrometric analysis. J Proteome Res 8: $870-876,2009$

33. van den Toorn HW, Mohammed S, Gouw JW, van Breukelen B and Heck AJ: Targeted scx based peptide fractionation for optimal sequencing by collision induced, and electron transfer dissociation. J Proteomics Bioinform 1: 379-388, 2008.

34. Jedrychowski MP, Huttlin EL, Haas W, Sowa ME, Rad R and Gygi SP: Evaluation of HCD- and CID-type fragmentation within their respective detection platforms for murine phosphoproteomics. Mol Cell Proteomics 10: M111.009910, 2011.

35. Nagaraj N, D'Souza RC, Cox J, Olsen JV and Mann M: Feasibility of large-scale phosphoproteomics with higher energy collisional dissociation fragmentation. J Proteome Res 9: 6786-6794, 2010.
36. Saba J, Dutta S, Hemenway E and Viner R: Increasing the productivity of glycopeptides analysis by using higher-energy collision dissociation-accurate mass-product-dependent electron transfer dissociation. Int J Proteomics 2012: 560391, 2012.

37. Liu M, Talmadge JE and Ding SJ: Development and application of site-specific proteomic approach for study protein S-nitrosylation. Amino acids 42: 1541-1551, 2012.

38. Palumbo AM, Tepe JJ and Reid GE: Mechanistic insights into the multistage gas-phase fragmentation behavior of phosphoserine- and phosphothreonine-containing peptides. J Proteome Res 7: 771-779, 2008.

39. Scott NE, Parker BL, Connolly AM, Paulech J, Edwards AV, Crossett B, Falconer L, Kolarich D, Djordjevic SP, Højrup P, et al: Simultaneous glycan-peptide characterization using hydrophilic interaction chromatography and parallel fragmentation by CID, higher energy collisional dissociation, and electron transfer dissociation MS applied to the N-linked glycoproteome of Campylobacter jejuni. Mol Cell Proteomics 10: M000031-MCP201, 2011.

40. Sobott F, Watt SJ, Smith J, Edelmann MJ, Kramer HB and Kessler BM: Comparison of CID versus ETD based MS/MS fragmentation for the analysis of protein ubiquitination. J Am Soc Mass Spectrom 20: 1652-1659, 2009.

41. Ross PL, Huang YN, Marchese JN, Williamson B, Parker K, Hattan S, Khainovski N, Pillai S, Dey S, Daniels S, et al: Multiplexed protein quantitation in Saccharomyces cerevisiae using amine-reactive isobaric tagging reagents. Mol Cell Proteomics 3: 1154-1169, 2004

42. Paradela A, Marcilla M, Navajas R, Ferreira L, RamosFernandez A, Fernández M, Mariscotti JF, García-del Portillo F and Albar JP: Evaluation of isotope-coded protein labeling (ICPL) in the quantitative analysis of complex proteomes. Talanta 80: 1496-1502, 2010.

43. Hsu JL, Huang SY and Chen SH: Dimethyl multiplexed labeling combined with microcolumn separation and MS analysis for time course study in proteomics. Electrophoresis 27: 3652-3660, 2006.

44. Liu H, Sadygov RG and Yates JR III: A model for random sampling and estimation of relative protein abundance in shotgun proteomics. Anal Chem 76: 4193-4201, 2004.

45. Bondarenko PV, Chelius D and Shaler TA: Identification and relative quantitation of protein mixtures by enzymatic digestion followed by capillary reversed-phase liquid chromatography-tandem mass spectrometry. Anal Chem 74: 4741-4749, 2002.

46. Huang Q, Yang L, Luo J, Guo L, Wang Z, Yang X, Jin W, Fang Y, Ye J, Shan B and Zhang Y: SWATH enables precise label-free quantification on proteome-scale. Proteomics 15: 1215-1223, 2015.

47. Mueller LN, Brusniak MY, Mani DR and Aebersold R: An assessment of software solutions for the analysis of mass spectrometry based quantitative proteomics data. J Proteome Res 7: 51-61, 2008.

48. Rajcevic U, Niclou SP and Jimenez CR: Proteomics strategies for target identification and biomarker discovery in cancer. Front Biosci (Landmark Ed) 14: 3292-3303, 2009.

49. Räst HL, Rosenberger G, Navarro P, Gillet L, Miladinović SM, Schubert OT, Wolski W, Collins BC, Malmström J, Malmström L and Aebersold R: OpenSWATH enables automated, targeted analysis of data-independent acquisition MS data. Nat Biotechnol 32: 219-223, 2014.

50. Khoury GA, Baliban RC and Floudas CA: Proteome-wide post-translational modification statistics: Frequency analysis and curation of the swiss-prot database. Sci Rep 1: pii: srep00090, 2011.

51. Yarbrough ML and Orth K: AMPylation is a new post-translational modiFICation. Nat Chem Biol 5: 378-379, 2009.

52. Mann M and Jensen ON: Proteomic analysis of post-translational modifications. Nat Biotechnol 21: 255-261, 2003.

53. Manning G, Plowman GD, Hunter T and Sudarsanam S: Evolution of protein kinase signaling from yeast to man. Trends Biochem Sci 27: 514-520, 2002.

54. Graves JD and Krebs EG: Protein phosphorylation and signal transduction. Pharmacol Ther 82: 111-121, 1999.

55. Hunter T: Protein kinases and phosphatases: The yin and yang of protein phosphorylation and signaling. Cell 80: 225-236, 1995.

56. Cohen P: The regulation of protein function by multisite phosphorylation-a 25 year update. Trends Biochem Sci 25: 596-601, 2000 . 
57. Kersten B, Agrawal GK, Iwahashi H and Rakwal R: Plant phosphoproteomics: A long road ahead. Proteomics 6: 5517-5528, 2006.

58. Jung K, Fried L, Behr S and Heermann R: Histidine kinases and response regulators in networks. Curr Opin Microbiol 15: $118-124,2012$

59. Kruppa M and Calderone R: Two-component signal transduction in human fungal pathogens. FEMS Yeast Res 6: 149-159, 2006.

60. Klumpp S and Krieglstein J: Reversible phosphorylation of histidine residues in proteins from vertebrates. Sci Signal 2: pe13, 2009.

61. Han SX, Wang LJ, Zhao J, Zhang Y, Li M, Zhou X, Wang J and Zhu Q: 14-kDa Phosphohistidine phosphatase plays an important role in hepatocellular carcinoma cell proliferation. Oncol Lett 4: 658-664, 2012.

62. Venter JC, Adams MD, Myers EW, Li PW, Mural RJ, Sutton GG, Smith HO, Yandell M, Evans CA, Holt RA, et al: The sequence of the human genome. Science 291: 1304-1351, 2001.

63. Lander ES, Linton LM, Birren B, Nusbaum C, Zody MC, Baldwin J, Devon K, Dewar K, Doyle M, FitzHugh W, et al: Initial sequencing and analysis of the human genome. Nature 409: 860-921, 2001.

64. Vasan S, Zhang X, Zhang X, Kapurniotu A, Bernhagen J, Teichberg S, Basgen J, Wagle D, Shih D, Terlecky I, et al: An agent cleaving glucose-derived protein crosslinks in vitro and in vivo. Nature 382: 275-278, 1996.

65. Blom N, Sicheritz-Pontén T, Gupta R, Gammeltoft S and Brunak S: Prediction of post-translational glycosylation and phosphorylation of proteins from the amino acid sequence. Proteomics 4: 1633-1649, 2004.

66. Tian Y and Zhang H: Characterization of disease-associated N-linked glycoproteins. Proteomics 13: 504-511, 2013.

67. Cylwik B, Lipartowska K, Chrostek L and Gruszewska E: Congenital disorders of glycosylation. Part II. Defects of protein O-glycosylation. Acta Biochim Pol 60: 361-368, 2013.

68. Furmanek A and Hofsteenge J: Protein C-mannosylation: Facts and questions. Acta Biochim Pol 47: 781-789, 2000.

69. Kinoshita T, Fujita M and Maeda Y: Biosynthesis, remodelling and functions of mammalian GPI-anchored proteins: Recent progress. J Biochem 144: 287-294, 2008.

70. Wong CH: Protein glycosylation: New challenges and opportunities. J Org Chem 70: 4219-4225, 2005.

71. Murakami Y: Pathogenesis of paroxysmal nocturnal hemoglobinuria. Rinsho Ketsueki 57: 1900-1907, 2016.

72. Lee RT, Lauc G and Lee YC: Glycoproteomics: Protein modifications for versatile functions. Meeting on glycoproteomics. EMBO Rep 6: 1018-1022, 2005.

73. Hart GW and Copeland RJ: Glycomics hits the big time. Cell 143: 672-676, 2010

74. Shahbazian MD and Grunstein M: Functions of site-specific histone acetylation and deacetylation. Annu Rev Biochem 76: 75-100, 2007.

75. Brooks CL and Gu W: Ubiquitination, phosphorylation and acetylation: The molecular basis for p53 regulation. Curr Opin Cell Biol 15: 164-171, 2003

76. Hammond JW, Cai D and Verhey KJ: Tubulin modifications and their cellular functions. Curr Opin Cell Biol 20: 71-76, 2008.

77. Arnesen T, Van Damme P, Polevoda B, Helsens K, Evjenth R, Colaert N, Varhaug JE, Vandekerckhove J, Lillehaug JR, Sherman F and Gevaert K: Proteomics analyses reveal the evolutionary conservation and divergence of $\mathrm{N}$-terminal acetyltransferases from yeast and humans. Proc Natl Acad Sci USA 106: 8157-8162, 2009.

78. Van Damme P, Hole K, Pimenta-Marques A, Helsens K Vandekerckhove J, Martinho RG, Gevaert K and Arnesen T: NatF contributes to an evolutionary shift in protein $\mathrm{N}$-terminal acetylation and is important for normal chromosome segregation. PLoS Genet 7: e1002169, 2011.

79. Brown JL: A comparison of the turnover of alpha-N-acetylated and nonacetylated mouse L-cell proteins. J Biol Chem 254 $1447-1449,1979$

80. Guo L, Münzberg H, Stuart RC, Nillni EA and Bjørbæk C: $\mathrm{N}$-acetylation of hypothalamic alpha-melanocyte-stimulating hormone and regulation by leptin. Proc Natl Acad Sci USA 101: 11797-11802, 2004.

81. Hwang CS, Shemorry A and Varshavsky A: N-terminal acetylation of cellular proteins creates specific degradation signals. Science 327: 973-977, 2010.
82. Behnia R, Panic B, Whyte JR and Munro S: Targeting of the Arf-like GTPase Arl3p to the Golgi requires N-terminal acetylation and the membrane protein Syslp. Nat Cell Biol 6 : 405-413, 2004.

83. Forte GM, Pool MR and Stirling CJ: N-terminal acetylation inhibits protein targeting to the endoplasmic reticulum. PLoS Biol 9: e1001073, 2011.

84. Gromyko D, Arnesen T, Ryningen A, Varhaug JE and Lillehaug JR: Depletion of the human No-terminal acetyltransferase A induces p53-dependent apoptosis and p53-independent growth inhibition. Int J Cancer 127: 2777-2789, 2010.

85. Yi CH, Pan H, Seebacher J, Jang IH, Hyberts SG, Heffron GJ Vander Heiden MG, Yang R, Li F, Locasale JW, et al: Metabolic regulation of protein $\mathrm{N}$-alpha-acetylation by $\mathrm{Bcl}-\mathrm{xL}$ promotes cell survival. Cell 146: 607-620, 2011

86. Kamita M, Kimura Y, Ino Y, Kamp RM, Polevoda B, Sherman F and Hirano $H: N(\alpha)$-Acetylation of yeast ribosomal proteins and its effect on protein synthesis. J Proteomics 74: 431-441, 2011.

87. Allfrey VG, Faulkner R and Mirsky AE: Acetylation and methylation of histones and their possible role in the regulation of RNA synthesis. Proc Natl Acad Sci USA 51: 786-794, 1964.

88. Gershey EL, Vidali G and Allfrey VG: Chemical studies of histone acetylation. The occurrence of epsilon- $\mathrm{N}$-acetyllysine in the f2a1 histone. J Biol Chem 243: 5018-5022, 1968.

89. Yang XJ and Seto E: Lysine acetylation: Codified crosstalk with other posttranslational modifications. Mol Cell 31: 449-461, 2008.

90. Haberland M, Montgomery RL and Olson EN: The many roles of histone deacetylases in development and physiology: Implications for disease and therapy. Nat Rev Genet 10: 32-42, 2009.

91. Shakespear MR, Halili MA, Irvine KM, Fairlie DP and Sweet MJ: Histone deacetylases as regulators of inflammation and immunity. Trends Immunol 32: 335-343, 2011.

92. Villagra A, Sotomayor E and Seto E: Histone deacetylases and the immunological network: Implications in cancer and inflammation. Oncogene 29: 157-173, 2010.

93. Mukherjee S, Hao YH and Orth K: A newly discovered post-translational modification-the acetylation of serine and threonine residues. Trends Biochem Sci 32: 210-216, 2007.

94. Paquette N, Conlon J, Sweet C, Rus F, Wilson L, Pereira A, Rosadini CV, Goutagny N, Weber AN, Lane WS, et al: Serine/threonine acetylation of TGF $\beta$-activated kinase (TAK1) by Yersinia pestis YopJ inhibits innate immune signaling. Proc Natl Acad Sci USA 109: 12710-12715, 2012

95. Ciechanover A and Iwai K: The ubiquitin system: From basic mechanisms to the patient bed. IUBMB Life 56: 193-201, 2004

96. Stieren ES, El Ayadi A, Xiao Y, Siller E, Landsverk ML, Oberhauser AF, Barral JM and Boehning D: Ubiquilin-1 is a molecular chaperone for the amyloid precursor protein. J Biol Chem 286: 35689-35698, 2011

97. Ciechanover A and Brundin P: The ubiquitin proteasome system in neurodegenerative diseases: Sometimes the chicken, sometimes the egg. Neuron 40: 427-446, 2003.

98. Scheffner M, Werness BA, Huibregtse JM, Levine AJ and Howley PM: The E6 oncoprotein encoded by human papillomavirus types 16 and 18 promotes the degradation of p53. Cell 63 1129-1136, 1990.

99. Dantuma NP and Masucci MG: The ubiquitin/proteasome system in Epstein-Barr virus latency and associated malignancies. Semin Cancer Biol 13: 69-76, 2003.

100. Karin M and Ben-Neriah Y: Phosphorylation meets ubiquitination: The control of NF-[kappa]B activity. Annu Rev Immunol 18: 621-663, 2000.

101. Shamu CE, Story CM, Rapoport TA and Ploegh HL: The pathway of US11-dependent degradation of MHC class I heavy chains involves a ubiquitin-conjugated intermediate. J Cell Biol 147: 45-58, 1999.

102. Sarge KD and Park-Sarge OK: Sumoylation and human disease pathogenesis. Trends Biochem Sci 34: 200-205, 2009

103. Desterro JM, Rodriguez MS, Kemp GD and Hay RT: Identification of the enzyme required for activation of the smal ubiquitin-like protein SUMO-1. J Biol Chem 274: 10618-10624, 1999.

104. Gong L, Kamitani T, Fujise K, Caskey LS and Yeh ET: Preferential interaction of sentrin with a ubiquitin-conjugating enzyme, Ubc9. J Biol Chem 272: 28198-28201, 1997.

105. Reverter D and Lima CD: Insights into E3 ligase activity revealed by a SUMO-RanGAP1-Ubc9-Nup358 complex. Nature 435: 687-692, 2005. 
106. Zhao J: Sumoylation regulates diverse biological processes. Cell Mol Life Sci 64: 3017-3033, 2007.

107. Kim KI and Baek SH: SUMOylation code in cancer development and metastasis. Mol Cells 22: 247-253, 2006.

108. Lin X, Sun B, Liang M, Liang YY, Gast A, Hildebrand J, Brunicardi FC, Melchior F and Feng XH: Opposed regulation of corepressor CtBP by SUMOylation and PDZ binding. Mol Cell 11: 1389-1396, 2003.

109. Sternsdorf T, Jensen K, Reich B and Will H: The nuclear dot protein sp100, characterization of domains necessary for dimerization, subcellular localization, and modification by small ubiquitin-like modifiers. J Biol Chem 274: 12555-12566, 1999.

110. Kamitani T, Kito K, Nguyen HP, Wada H, Fukuda-Kamitani T and Yeh ET: Identification of three major sentrinization sites in PML. J Biol Chem 273: 26675-26682, 1998.

111. Melchior F: SUMO-nonclassical ubiquitin. Annu Rev Cell Dev Biol 16: 591-626, 2000.

112. Zheng G and Yang YC: ZNF76, a novel transcriptional repressor targeting TATA-binding protein, is modulated by sumoylation. J Biol Chem 279: 42410-42421, 2004

113. Pichler A, Knipscheer P, Oberhofer E, van Dijk WJ, Körner R, Olsen JV, Jentsch S, Melchior F and Sixma TK: SUMO modification of the ubiquitin-conjugating enzyme E2-25K. Nat Struct Mol Biol 12: 264-269, 2005 .

114. Matunis MJ, Coutavas E and Blobel G: A novel ubiquitin-like modification modulates the partitioning of the Ran-GTPase-activating protein RanGAP1 between the cytosol and the nuclear pore complex. J Cell Biol 135: 1457-1470, 1996.

115. Mahajan R, Delphin C, Guan T, Gerace L and Melchior F: A small ubiquitin-related polypeptide involved in targeting RanGAP1 to nuclear pore complex protein RanBP2. Cell 88 97-107, 1997.

116. Cheng TS, Chang LK, Howng SL, Lu PJ, Lee CI and Hong YR SUMO-1 modification of centrosomal protein hNinein promotes hNinein nuclear localization. Life Sci 78: 1114-1120, 2006.

117. Desterro JM, Rodriguez MS and Hay RT: SUMO-1 modification of IkappaBalpha inhibits NF-kappaB activation. Mol Cell 2 : 233-239, 1998.

118. Stadtman ER: Protein oxidation and aging. Science 257: $1220-1224,1992$

119. Chang TC, Chou WY and Chang GG: Protein Oxidation and Turnover. J Biomed Sci 7: 357-363, 2000.

120. Lee DY, Teyssier C, Strahl BD and Stallcup MR: Role of protein methylation in regulation of transcription. Endocr Rev 26 : $147-170,2005$

121. Aletta JM, Cimato TR and Ettinger MJ: Protein methylation: A signal event in post-translational modification. Trends Biochem Sci 23: 89-91, 1998

122. Nadolski MJ and Linder ME: Protein lipidation. FEBS J 274: 5202-5210, 2007.

123. Casey P: Protein lipidation in cell signaling. Science 268: 221-225, 1995.

124. Rikova K, Guo A, Zeng Q, Possemato A, Yu J, Haack H, Nardone J, Lee K, Reeves C, Li Y, et al: Global survey of phosphotyrosine signaling identifies oncogenic kinases in lung cancer. Cell 131: 1190-1203, 2007.

125. Ong SE, Mittler G and Mann M: Identifying and quantifying in vivo methylation sites by heavy methyl SILAC. Nat Methods 1: 119-126, 2004

126. Zhang J, Sprung R, Pei J, Tan X, Kim S, Zhu H, Liu CF, Grishin NV and Zhao Y: Lysine acetylation is a highly abundant and evolutionarily conserved modification in Escherichia coli. Mol Cell Proteomics 8: 215-225, 2009.

127. Vocadlo DJ, Hang HC, Kim EJ, Hanover JA and Bertozzi CR: A chemical approach for identifying O-GlcNAc-modified proteins in cells. Proc Natl Acad Sci USA 100: 9116-9121, 2003.

128. Kaji H, Saito H, Yamauchi Y, Shinkawa T, Taoka M, Hirabayashi J, Kasai K, Takahashi N and Isobe T: Lectin affinity capture, isotope-coded tagging and mass spectrometry to identify N-linked glycoproteins. Nat Biotechnol 21: 667-672, 2003.

129. Derakhshan B, Wille PC and Gross SS: Unbiased identification of cysteine S-nitrosylation sites on proteins. Nat Protoc 2 1685-1691, 2007.

130. Sprung R, Nandi A, Chen Y, Kim SC, Barma D, Falck JR and Zhao Y: Tagging-via-substrate strategy for probing O-GlcNAc modified proteins. J Proteome Res 4: 950-957, 2005.

131. Kostiuk MA, Corvi MM, Keller BO, Plummer G, Prescher JA, Hangauer MJ, Bertozzi CR, Rajaiah G, Falck JR and Berthiaume LG: Identification of palmitoylated mitochondrial proteins using a bio-orthogonal azido-palmitate analogue. FASEB J 22: 721-732, 2008
132. Xiong L, Andrews D and Regnier F: Comparative proteomics of glycoproteins based on lectin selection and isotope coding. J Proteome Res 2: 618-625, 2003

133. Yang Z, Harris LE, Palmer-Toy DE and Hancock WS: Multilectin affinity chromatography for characterization of multiple glycoprotein biomarker candidates in serum from breast cancer patients. Clin Chem 52: 1897-1905, 2006.

134. Madera M, Mann B, Mechref Y and Novotny MV: Efficacy of glycoprotein enrichment by microscale lectin affinity chromatography. J Sep Sci 31: 2722-2732, 2008.

135. Andersson L and Porath J: Isolation of phosphoproteins by immobilized metal $\left(\mathrm{Fe}^{3+}\right)$ affinity chromatography. Anal Biochem 154: 250-254, 1986.

136. Posewitz MC and Tempst P: Immobilized gallium(III) affinity chromatography of phosphopeptides. Anal Chem 71: 2883-2892, 1999.

137. Dubrovska A and Souchelnytskyi S: Efficient enrichment of intact phosphorylated proteins by modified immobilized metal-affinity chromatography. Proteomics 5: 4678-4683, 2005.

138. Pinkse MW, Uitto PM, Hilhorst MJ, Ooms B and Heck AJ: Selective isolation at the femtomole level of phosphopeptides from proteolytic digests using 2D-NanoLC-ESI-MS/MS and titanium oxide precolumns. Anal Chem 76: 3935-3943, 2004.

139. Larsen MR, Thingholm TE, Jensen ON, Roepstorff $P$ and Jørgensen TJD: Highly selective enrichment of phosphorylated peptides from peptide mixtures using titanium dioxide microcolumns. Molecular Cellular Proteomics 4: 873-886, 2005.

140. Thingholm TE, Jensen ON, Robinson PJ and Larsen MR: SIMAC (sequential elution from IMAC), a phosphoproteomics strategy for the rapid separation of monophosphorylated from multiply phosphorylated peptides. Mol Cell Proteomics 7: 661-671, 2008

141. Moshirfar M, Pierson K, Hanamaikai K, Santiago-Caban L, Muthappan V and Passi SF: Artificial tears potpourri: A literature review. Clin Ophthalmol 8: 1419-1433, 2014.

142. Okrojek R, Grus FH, Matheis N and Kahaly GJ: Proteomics in autoimmune thyroid eye disease. Horm Metab Res 41: 465-470, 2009.

143. Zhou L, Beuerman RW, Chew AP, Koh SK, Cafaro TA, Urrets-Zavalia EA, Urrets-Zavalia JA, Li SF and Serra HM: Quantitative Analysis of N-Linked Glycoproteins in Tear Fluid of Climatic Droplet Keratopathy by Glycopeptide Capture and iTRAQ. J Proteome Res 8: 1992-2003, 2009.

144. de Souza GA, de Godoy LM and Mann M: Identification of 491 proteins in the tear fluid proteome reveals a large number of proteases and protease inhibitors. Genome Biol 7: R72, 2006.

145. Zhou L, Zhao SZ, Koh SK, Chen L, Vaz C, Tanavde V, Li XR and Beuerman RW: In-depth analysis of the human tear proteome. J Proteomics 75: 3877-3885, 2012

146. Zhou L, Beuerman RW, Chan CM, Zhao SZ, Li XR, Yang H, Tong L, Liu S, Stern ME and Tan D: Identification of tear fluid biomarkers in dry eye syndrome using iTRAQ quantitative proteomics. J Proteome Res 8: 4889-4905, 2009.

147. Lema I, Brea D, Rodríguez-González R, Díez-Feijoo E and Sobrino T: Proteomic analysis of the tear film in patients with keratoconus. Mol Vis 16: 2055-2061, 2010.

148. Csősz É, Boross P, Csutak A, Berta A, Tóth F, Póliska S, Török Z and Tózsér J: Quantitative analysis of proteins in the tear fluid of patients with diabetic retinopathy. J Proteomics 75: 2196-2204, 2012.

149. Wong TT, Zhou L, Li J, Tong L, Zhao SZ, Li XR, Yu SJ, Koh SK and Beuerman RW: Proteomic profiling of inflammatory signaling molecules in the tears of patients on chronic glaucoma medication. Invest Ophthalmol Vis Sci 52: 7385-7391, 2011.

150. Argueso P and Sumiyoshi M: Characterization of a carbohydrate epitope defined by the monoclonal antibody $\mathrm{H} 185$ : Sialic acid O-acetylation on epithelial cell-surface mucins. Glycobiology 16: 1219-1228, 2006.

151. Lei Z, Beuerman RW, Chew AP, Koh SK, Cafaro TA, Urrets-Zavalia EA, Urrets-Zavalia JA, Li SF and Serra HM: Quantitative analysis of N-linked glycoproteins in tear fluid of climatic droplet keratopathy by glycopeptide capture and iTRAQ. J Proteome Res 8: 1992-2003, 2009.

152. You J, Fitzgerald A, Cozzi PJ, Zhao Z, Graham P, Russell PJ, Walsh BJ, Willcox M, Zhong L, Wasinger V and Li Y: Post-translation modification of proteins in tears. Electrophoresis 31: 1853-1861, 2010.

153. Vieira AC, An HJ, Ozcan S, Kim JH, Lebrilla CB and Mannis MJ: Glycomic analysis of tear and saliva in ocular rosacea patients: The search for a biomarker. Ocul Surf 10: $184-192,2012$ 
154. Dickinson DP and Thiesse M: A major human lacrimal gland mRNA encodes a new proline-rich protein family member. Invest Ophthalmol Vis Sci 36: 2020-2031, 1995.

155. Perumal N, Funke S, Pfeiffer N and Grus FH: Characterization of Lacrimal Proline-Rich Protein 4 (PRR4) in human tear proteome. Proteomics 14: 1698-1709, 2014.

156. Dyrlund TF, Poulsen ET, Scavenius C, Nikolajsen CL, Thøgersen IB, Vorum H and Enghild JJ: Human cornea proteome: Identification and quantitation of the proteins of the three main layers including epithelium, stroma and endothelium. J Proteome Res 11: 4231-4239, 2012.

157. Narayan M, Mirza SP and Twining SS: Identification of phosphorylation sites on extracellular corneal epithelial cell maspin. Proteomics 11: 1382-1390, 2011.

158. Kehasse A, Rich CB, Lee A, McComb ME, Costello CE and Trinkaus-Randall V: Epithelial wounds induce differential phosphorylation changes in response to purinergic and EGF receptor activation. Am J Pathol 183: 1841-1852, 2013.

159. Iwatsuka K, Iwamoto $H$, Kinoshita $M$, Inada $K$, Yasueda $S$ and Kakehi K: Comparative studies of $\mathrm{N}$-glycans and glycosaminoglycans present in SIRC (Statens Seruminstitut rabbit cornea) cells and corneal epithelial cells from rabbit eyes. Curr Eye Res 39: 686-694, 2014

160. Truscott RJ: Age-related nuclear cataract-oxidation is the key. Exp Eye Res 80: 709-725, 2005.

161. Michael R and Bron AJ: The ageing lens and cataract: A model of normal and pathological ageing. Philos Trans R Soc Lond B Biol Sci 366: 1278-1292, 2011.

162. Lampi KJ, Wilmarth PA, Murray MR and David LL: Lens $\beta$-crystallins: The role of deamidation and related modifications in aging and cataract. Prog Biophys Mol Biol 115: 21-31, 2014

163. Sharma KK and Santhoshkumar P: Lens aging: Effects of crystallins. Biochim Biophys Acta 1790: 1095-1108, 2009.

164. Asomugha CO, Gupta R and Srivastava OP: Identification of crystallin modifications in the human lens cortex and nucleus using laser capture microdissection and CyDye labeling. Mol Vis 16: 476-494, 2010.

165. Fujii N, Sakaue H and Sasaki H: A rapid, comprehensive liquid chromatography-mass spectrometry (LC-MS)-based survey of the Asp isomers in crystallins from human cataract lenses. J Biol Chem 287: 39992-40002, 2012.

166. Hains PG and Truscott RJ: Post-translational modifications in the nuclear region of young, aged, and cataract human lenses. J Proteome Res 6: 3935-3943, 2007.

167. Kamei A, Takeuchi N, Nagai M and Mori S: Post-translational modification of betaH-crystallin of bovine lens with aging. Biol Pharm Bull 26: 1715-1720, 2003.

168. Schaefer H, Chamrad DC, Herrmann M, Stuwe J, Becker G, Klose J, Blueggel M, Meyer HE and Marcus K: Study of posttranslational modifications in lenticular alphaA-Crystallin of mice using proteomic analysis techniques. Biochim Biophys Acta 1764: 1948-1962, 2006

169. Truscott RJ, Mizdrak J, Friedrich MG, Hooi MY, Lyons B, Jamie JF, Davies MJ, Wilmarth PA and David LL: Is protein methylation in the human lens a result of non-enzymatic methylation by S-adenosylmethionine? Exp Eye Res 99: 48-54, 2012.

170. Ueda Y, Duncan MK and David LL: Lens proteomics: The accumulation of crystallin modifications in the mouse lens with age. Invest Ophthalmol Vis Sci 43: 205-215, 2002.

171. Yanshole LV, Cherepanov IV, Snytnikova OA, Yanshole VV, Sagdeev RZ and Tsentalovich YP: Cataract-specific posttranslational modifications and changes in the composition of urea-soluble protein fraction from the rat lens. Mol Vis 19 2196-2208, 2013

172. Chiou SH, Huang CH, Lee IL, Wang YT, Liu NY, Tsay YG, Chen YJ: Identification of in vivo phosphorylation sites of lens proteins from porcine eye lenses by a gel-free phosphoproteomics approach. Mol Vis 16: 294-302, 2010.

173. Huang CH, Wang YT, Tsai CF, Chen YJ, Lee JS and Chiou SH: Phosphoproteomics characterization of novel phosphorylated sites of lens proteins from normal and cataractous human eye lenses. Mol Vis 17: 186-198, 2011.

174. Ball LE, Garland DL, Crouch RK and Schey KL: Post-translational modifications of aquaporin 0 (AQP0) in the normal human lens: Spatial and temporal occurrence. Biochemistry 43: 9856-9865, 2004.

175. Wang Z, Han J and Schey KL: Spatial differences in an integral membrane proteome detected in laser capture microdissected samples. J Proteome Res 7: 2696-2702, 2008.
176. Schey KL, Gutierrez DB, Wang Z, Wei J and Grey AC: Novel fatty acid acylation of lens integral membrane protein aquaporin-0. Biochemistry 49: 9858-9865, 2010.

177. Kim T, Kim SJ, Kim K, Kang UB, Lee C, Park KS, Yu HG and Kim Y: Profiling of vitreous proteomes from proliferative diabetic retinopathy and nondiabetic patients. Proteomics 7: 4203-4215, 2007.

178. Bahk SC, Jang JU, Choi CU, Lee SH, Park ZY, Yang JY, Kim JD, Yang YS and Chung HT: Post-translational modification of crystallins in vitreous body from experimental autoimmune uveitis of rats. J Proteome Res 6: 3891-3898, 2007.

179. Hong SM and Yang YS: A potential role of crystallin in the vitreous bodies of rats after ischemia-reperfusion injury. Korean J Ophthalmol 26: 248-254, 2012.

180. Griciuc A, Roux MJ, Merl J, Giangrande A, Hauck SM, Aron L and Ueffing $\mathrm{M}$ : Proteomic survey reveals altered energetic patterns and metabolic failure prior to retinal degeneration. J Neurosci 34: 2797-2812, 2014.

181. Keenan TD, Clark SJ, Unwin RD, Ridge LA, Day AJ and Bishop PN: Mapping the differential distribution of proteoglycan core proteins in the adult human retina, choroid, and sclera. Invest Ophthalmol Vis Sci 53: 7528-7538, 2012.

182. Tababat-Khani P, de la Torre C, Canals F, Bennet H, Simo R, Hernandez C, Fex M, Agardh CD, Hansson O and Agardh E: Photocoagulation of human retinal pigment epithelium in vitro: Unravelling the effects on ARPE-19 by transcriptomics and proteomics. Acta ophthalmol 93: 348-354, 2015.

183. Zhang SY, Li BY, Li XL, Cheng M, Cai Q, Yu F, Wang WD, Tan M, Yan G, Hu SL and Gao HQ: Effects of phlorizin on diabetic retinopathy according to isobaric tags for relative and absolute quantification-based proteomics in $\mathrm{db} / \mathrm{db}$ mice. Mol Vis 19: 812-821, 2013.

184. Ablonczy Z, Goletz P, Knapp DR and Crouch RK: Mass spectrometric analysis of porcine rhodopsin. Photochem Photobiol 75: 316-321, 2002

185. Saraswathy S and Rao NA: Posttranslational modification of differentially expressed mitochondrial proteins in the retina during early experimental autoimmune uveitis. Mol Vis 17: 1814-1821, 2011

186. Chen F, Ng PS, Faull KF and Lee RH: Cone photoreceptor betagamma-transducin: Posttranslational modification and interaction with phosducin. Invest Ophthalmol Vis Sci 44: 4622-4629, 2003

187. Kassai H, Satomi Y, Fukada Y and Takao T: Top-down analysis of protein isoprenylation by electrospray ionization hybrid quadrupole time-of-flight tandem mass spectrometry; the mouse Tgamma protein. Rapid Commun Mass Spectrom 19: 269-274, 2005.

188. Salom D, Wang B, Dong Z, Sun W, Padayatti P, Jordan S, Salon JA and Palczewski K: Post-translational modifications of the serotonin type 4 receptor heterologously expressed in mouse rod cells. Biochemistry 51: 214-224, 2011.

189. Tsybovsky Y, Wang B, Quazi F, Molday RS and Palczewski K: Posttranslational modifications of the photoreceptor-specific ABC transporter ABCA4. Biochemistry 50: 6855-6866, 2011.

190. Zhao X, Sidoli S, Wang L, Wang W, Guo L, Jensen ON and Zheng L: Comparative proteomic analysis of histone post-translational modifications upon ischemia/reperfusion-induced retinal injury. J Proteome Res 13: 2175-2186, 2014.

191. Morgan IG, Ohno-Matsui K and Saw SM: Myopia. Lancet 379: 1739-1748, 2012.

192. Pan CW, Ramamurthy D and Saw SM: Worldwide prevalence and risk factors for myopia. Ophthalmic Physiol Opt 32: 3-16, 2012.

193. Lin LL, Shih YF, Hsiao CK and Chen CJ: Prevalence of myopia in Taiwanese schoolchildren: 1983 to 2000. Ann Acad Med Singapore 33: 27-33, 2004.

194. Sun J, Zhou J, Zhao P, Lian J, Zhu H, Zhou Y, Sun Y, Wang Y, Zhao L, Wei Y, et al: High prevalence of myopia and high myopia in 5060 Chinese university students in Shanghai. Invest Ophthalmol Vis Sci 53: 7504-7509, 2012.

195. Wallman J, Gottlieb MD, Rajaram V and Fugate-Wentzek LA: Local retinal regions control local eye growth and myopia. Science 237: 73-77, 1987.

196. Hodos W and Kuenzel WJ: Retinal-image degradation produces ocular enlargement in chicks. Invest Ophthalmol Vis Sci 25: 652-659, 1984

197. Lam TC, Li KK, Lo SC, Guggenheim JA and To CH: Application of fluorescence difference gel electrophoresis technology in searching for protein biomarkers in chick myopia. J Proteome Res 6: 4135-4149, 2007. 
198. Jostrup R, Shen W, Burrows JT, Sivak JG, McConkey BJ and Singer TD: Identification of myopia-related marker proteins in tilapia retinal, RPE, and choroidal tissue following induced form deprivation. Curr Eye Res 34: 966-975, 2009.

199. Barathi VA, Chaurasia SS, Poidinger M, Koh SK, Tian D, Ho C, Iuvone PM, Beuerman RW and Zhou L: Involvement of GABA transporters in atropine-treated myopic retina as revealed by iTRAQ quantitative proteomics. J Proteome Res 13: 4647-4658, 2014.

200.Chen B, Yu F, Li KK, Chun RK, Lam TC and To CH: Qualitative and quantitative phosphoproteomics analysis of chick retina of Tio2-enriched strategy. Presented at the 13th Annual World Congress of the Human Proteome Organization, 2014. http://hdl.handle.net/10397/59149.

201. Lee H, Chung H, Lee SH and Jahng WJ: Light-induced phosphorylation of crystallins in the retinal pigment epithelium. Int $\mathrm{J}$ Biol Macromol 48: 194-201, 2011.
202. Kanan Y, Siefert JC, Kinter M and Al-Ubaidi MR: Complement factor $\mathrm{H}$, vitronectin, and opticin are tyrosine-sulfated proteins of the retinal pigment epithelium. PLoS One 9: e105409, 2014.

203. Lee H, Chung H, Arnouk H, Lamoke F, Hunt RC, Hrushesky WJ, Wood PA, Lee SH and Jahng WJ: Cleavage of the retinal pigment epithelium-specific protein RPE65 under oxidative stress. Int J Biol Macromol 47: 104-108, 2010.

204. Yuan Q, Kaylor JJ, Miu A, Bassilian S, Whitelegge JP and Travis GH: Rpe65 isomerase associates with membranes through an electrostatic interaction with acidic phospholipid headgroups. J Biol Chem 285: 988-999, 2010.

205. DiMauro MA, Nandi SK, Raghavan CT, Kar RK, Wang B, Bhunia A, Nagaraj RH and Biswas A: Acetylation of Gly1 and Lys2 promotes aggregation of human $\gamma \mathrm{D}$-crystallin. Biochemistry 53: 7269-7282, 2014. 